\title{
Forests protect aquatic communities from detrimental impact by volcanic deposits in the tropical Andes (Ecuador)
}

\author{
Encarni Montoya $^{1,2}$ (D) $\cdot$ Frazer Matthews-Bird ${ }^{1} \cdot$ Stephen J. Brooks ${ }^{3} \cdot$ William D. Gosling ${ }^{1,4}$
}

Received: 4 January 2021 / Accepted: 29 April 2021 / Published online: 15 May 2021

(C) The Author(s) 2021

\begin{abstract}
Volcanic activity impacts ecosystems sometimes with multiple, complex and long-lasting consequences, including volcanic tephra (airborne material) causing widespread disruptions. We study the effects of tephra deposition around two tropical lakes of Ecuador using a multi-proxy analysis of lake sediment archives spanning the last 2000 years. We present the dynamics of terrestrial vegetation (pollen), aquatic macroinvertebrate fauna (chironomids) and organic matter (stable isotopes) in: (i) a high elevation, stream-connected, open alpine grassland (Andean páramo) and (ii) a mid-elevation, stream-isolated, pre-montane forest. Páramo vegetation showed a slight increase in herbs and quick recovery after the tephra deposition; however, the aquatic community suffered a regime shift not reversed today c. 1500 years after the event. In the pre-montane location, the canopy opened up following tephra deposition, and it took c. 150 years to return to pre-impact levels. At the forested site, no major changes in the aquatic fauna were observed related to the tephra deposition. We hypothesise that the forest acted as a protective barrier preventing a large fallout of ash into the aquatic system. Forest not only acted as a buffer for ash falling into the water from the air, but also prevented landslides of tephra by enhancing soil stability, contrary to what was observed in the open system. We demonstrate the protective ecosystem service that forests play in sustaining ecological resilience and water quality facing natural (volcanic) disturbance. The ongoing deforestation of tropical regions therefore might increase the vulnerability of aquatic ecosystems, threatening the water quality for ecosystems and human populations.
\end{abstract}

Keywords Ecosystem interactions $\cdot$ Long-term data $\cdot$ Natural-based solutions $\cdot$ Palaeoecology $\cdot$ Resilience $\cdot$ Tephras

Communicated by Victor Resco de Dios

Encarni Montoya

emontoya@liverpool.ac.uk

Frazer Matthews-Bird

frazermatthewsbird@gmail.com

Stephen J. Brooks

S.Brooks@nhm.ac.uk

William D. Gosling

W.D.Gosling@uva.nl

1 School of Environment, Earth \& Ecosystem Sciences, The Open University, Walton Hall, Milton Keynes MK7 6AA, UK

2 Department of Geography \& Planning, School of Environmental Sciences, University of Liverpool, L69 7ZT, Liverpool, UK

3 Life Sciences, Natural History Museum, Cromwell Road, London SW7 5BD, UK

4 Ecosystems \& Landscape Dynamics, Institute of Biodiversity \& Ecosystem Dynamics (IBED), University of Amsterdam, Postbus 94248, 1090, GE Amsterdam, The Netherlands

\section{Introduction}

Volcanic events present a significant hazard to human and ecological systems through the eruption of gases, lava and airborne material. The deposition of tephra (volcanic airborne material $<64 \mathrm{~mm}$ in diameter) is the most common and widespread disturbance produced by volcanoes (del Moral and Grishin 1999), and has been identified as a key factor in community shifts in a variety of ecosystems (Antos and Zobel 2005; Haruki and Tsuyuzaki 2001; Hotes et al. 2006; Hughes et al. 2013; Millar et al. 2006; Allen and Huntley 2018). The scale of impact of a tephra deposition on an ecosystem is contingent on the local abiotic and biotic characteristics (e.g. catchment topography and community structure), and the interplay of those characteristics with the volcanic event (e.g. volume of tephra emitted and its chemical composition) (Dale et al. 2005; Foster et al. 1998). The study of biological responses to past tephra depositions allows local impact characteristics to be assessed, and thus provides insights into potential ecosystem changes that are relevant for 
the development of achievable and effective strategies to mitigate potential negative impacts.

Here we assess the impact of past tephra deposition on terrestrial and aquatic communities from two contrasting locations in the tropical Andes (Ecuador). Information on past volcanic and ecosystem function was obtained by examining material extracted from sedimentary deposits, which had accumulated over the last 2000 years, recovered from two small lakes. Specifically, volcanic events were identified by the presence of tephra shards; terrestrial ecosystem dynamics were characterised through pollen analysis; aquatic community stability was assessed by aquatic macroinvertebrate fauna (chironomids); and the origin of the organic matter present in the watershed (terrestrial/aquatic plants, $\mathrm{C}_{3} / \mathrm{C}_{4}$ plants) was determined from stable isotope analysis of $\mathrm{C}$ and $\mathrm{N}$. These data were used to: (i) parameterise interactions within communities facing an external stressor, (ii) identify cascades between terrestrial and aquatic communities and (iii) assess the use of long-term ecological data for management, restoration and conservation initiatives through the use of naturebased solutions and enhancement of ecosystems services.

\section{Material and methods}

\section{Study sites}

The two study sites (Lagunas Baños and Pindo) are located in central Ecuador on the eastern Andean flank approximately $130 \mathrm{~km}$ apart (Fig. 1a). The Andean flank is a highly tectonic region with a long history of volcanic activity (e.g. Barberi et al. 1988). Both lakes analysed in this study lie within the direct influence of the Northern Volcanic Zone (NVZ) that spans northern Ecuador and Colombia, where over 20 volcanoes are active today and throughout the Quaternary (Hall et al. 2008). Previous work on these lakes identified that the sediments contained evidence of large tephra events (sedimentary thickness $>5 \mathrm{~cm}$ ) within the last 2000 years (Matthews-Bird et al. 2017), making them suitable for this study. In this previous study, the characteristics of the volcanic ash that produced the tephras as well as the topographic conditions of both locations were analysed, confirming the comparability of both events for the present study. The results showed that the chemistry of the tephras analysed are very similar, and that the thickness of the ash deposit was a major driver involved in the aquatic community dynamics (Matthews-Bird et al. 2017).

Laguna Baños $\left(0^{\circ} 19.328^{\prime} \mathrm{S}-78^{\circ} 09.175^{\prime} \mathrm{W}\right)$ is a small glacial lake located in the high lake district region of Cayambé Coca National Park, surrounded by Andean páramo vegetation (tropical alpine grassland) containing patches of woodland, at an elevation of $3821 \mathrm{~m}$ above sea level (a.s.1.) (Fig. 1b.1). Mean annual temperature is c. $5.7^{\circ} \mathrm{C}$ and annual precipitation is c. $1300 \mathrm{~mm}$ per year (Hijmans et al. 2005). Although there is little seasonal variation in temperature, daily variations can be c. $20^{\circ} \mathrm{C}$ (Jørgensen and León-Yánez 1999). Laguna Baños is located at the base of a glacial valley, roughly circular and is the last lake in an elevational sequence of three lakes created by past glaciation, which today are connected by a small stream (Fig. 1b.2). Consequently, L. Baños receives water through inflow, surface run-off, and direct precipitation. At the time of sampling (October 2008), L. Baños contained a large number of aquatic plants and abundant algae with a strong lotic influence. Around L. Baños, the vegetation was found to be characteristic of grass páramo (Jørgensen and León-Yánez 1999); dominated by Calamagrostis sp. and Festuca sp. (Poaceae), with scattered patches of shrubby vegetation (Asteraceae) and mixed Polylepis sp. (Rosaceae) dominated woodlands (Table S1). The lake is remote and beyond the influence of direct human activity such as agriculture and urbanization, but is located close to the entrance of the park where the road access ends and a ranger station exists. The sedimentary sequence recovered from L. Baños is characterised by a thick tephra deposit that probably resulted from an eruptive event in the Cosanga volcanic region that occurred c. 1500 years ago (Hall and Mothes 2010). This single volcanic event is characterised by two tephra layers (Figs. 2 and S1) due to subsequent redeposition ( $<40$ years) of tephra falling elsewhere in the catchment and entering the lake. Previous work hypothesised that the entrance of this second tephra into the lake could have been either through slope wash and/or fluvial processes (Matthews-Bird et al. 2017).

Laguna Pindo $\left(1^{\circ} 27.132^{\prime} \mathrm{S}-78^{\circ} 04.847^{\prime} \mathrm{W}\right)$ is a small shallow lake, roughly circular shaped, located in Pastaza province at an elevation of $1248 \mathrm{~m}$ a.s.1. (Fig. 1c.1). Mean annual temperature is c. $20^{\circ} \mathrm{C}$ with little seasonal variation; annual precipitation can reach c. $4000 \mathrm{~mm}$ per year (Hijmans et al. 2005). The lake is located on the edge of a thrust, and currently is not directly fed by an in-flow and has no visible out-flow (Fig. 1c.2); therefore, the lake receives water from surface runoff and direct precipitation only. Laguna Pindo lies within an area classified as pre-montane rain forest, between the high elevation páramo vegetation and lowland Amazonia rain forest (Harling 1979). At the time of sample collection (January 2013), the lake was heavily overgrown with aquatic plants (Cyperaceae) and completely vegetated to the water's edge. A closed secondary forest with a canopy of 15-25 m surrounds the lake. The vegetation in the immediate vicinity is dominated by species of Melastomataceae, Araceae, Cecropiaceae, Euphorbiaceae, Myrtaceae, Rubiaceae, Myristicaceae, Asteraceae and Mimosaceae. Lianas, epiphytes (Bromeliaceae, Orchidaceae) and tree ferns are also common (Table S2). The lake is remote and beyond the influence of direct human activity, such as agriculture and urbanization, except for the presence of a biological station nearby. 


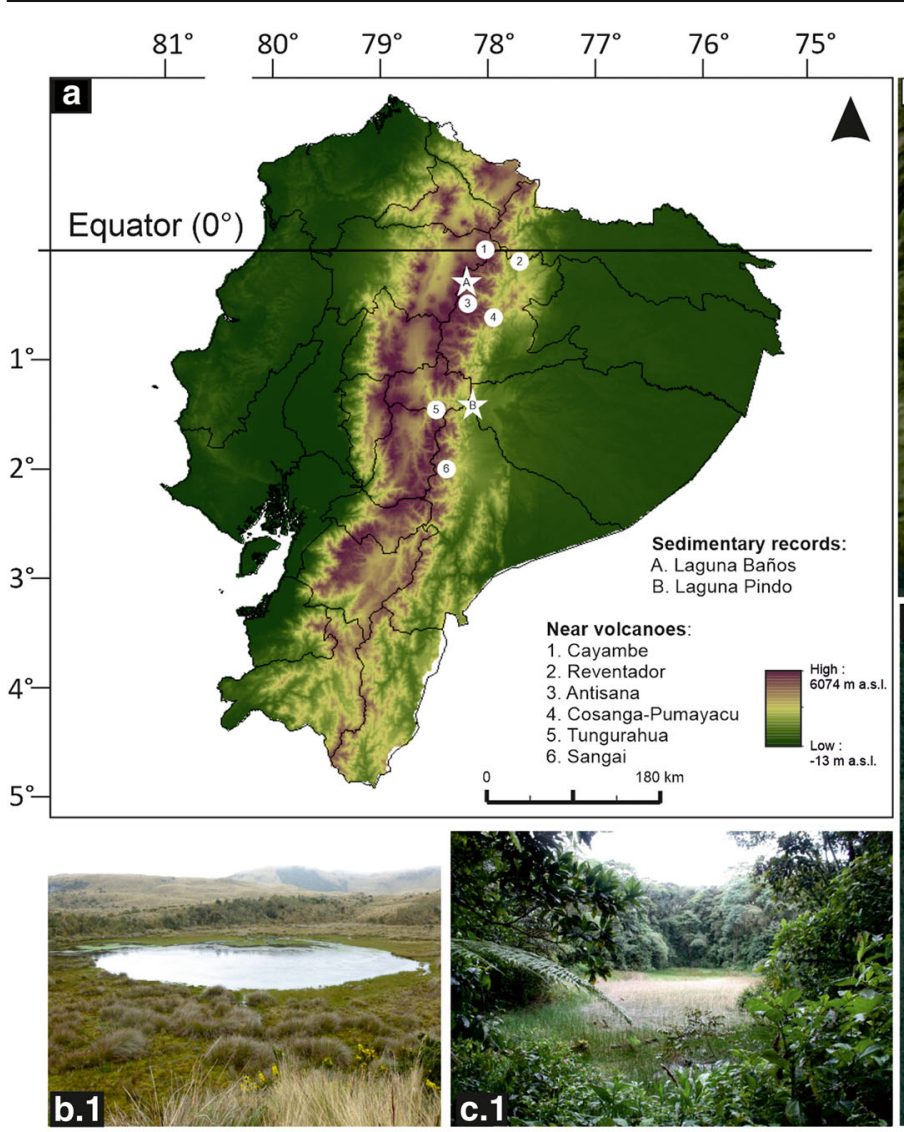

Fig. 1 (a) Map of Ecuador, showing location of the lakes studied marked as stars (A: Laguna Baños and, B: Laguna Pindo) and the main volcanoes close to the lakes (circles). (b) Laguna Baños: image of the lake (b.1), and Google Earth view of the catchment (b.2: numbers 1 and 2 indicate the sequential water bodies forming the laguna connected by a stream, being the present study the last one (number 2)), where a patch of Polylepis-

Within the sediments of L. Pindo, a tephra layer is preserved, likely originating from a Tungurahua volcano event occurring c. 900 years ago (Le Pennec et al. 2008).

\section{Methodology}

A $4.04 \mathrm{~m}$ sediment core was recovered from L. Baños, and $9.24 \mathrm{~m}$ core was recovered from L. Pindo, using a cammodified Livingstone piston corer (Livingstone 1955; Colinvaux et al. 1999). The relationship between the amount of sediment accumulated and time taken for deposition was determined through the radiocarbon dating of eight (L. Baños) and 18 (L. Pindo) sub-samples of bulk sediment or wood remains (Table S3). The raw radiocarbon dates were calibrated using IntCal13.14c and SHCal.13.14c for L. Baños and L. Pindo respectively (Hogg et al. 2013; Reimer et al. 2013). The results were used to construct age-depth models in R using the statistical package 'clam.R' (Blaauw 2010), that have been published elsewhere (Matthews-Bird et al. 2017; Montoya et al. 2018), and are included in the Supplementary material

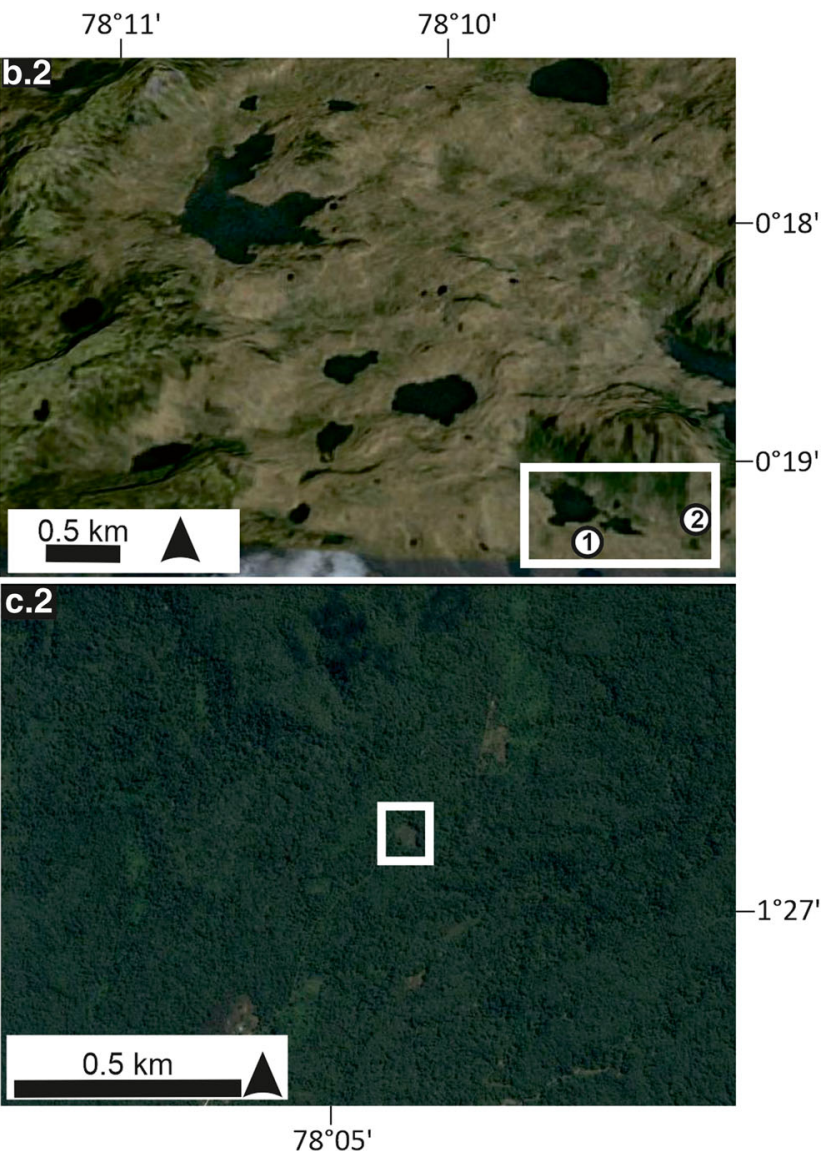

dominated woodland can be observed at $200-300 \mathrm{~m} \mathrm{~N}-\mathrm{NW}$ of the lake. (c) Laguna Pindo: Image of the lake (c.1), and Google Earth view of the catchment (c.2). Google Earth access on March 2020. Note the differences in the scale used for both images and in the openness of the catchment showed by colours in the online version (green/dark = forest; yellow/light $=$ grassland $)$

(Figs. S1 and S2). Ages of samples are referred to in calibrated years before present (cal yr BP), or in years before or in the common era (BCE or $\mathrm{CE})$.

Sub-samples $\left(1 \mathrm{~cm}^{3}\right.$ for pollen and around $1 \mathrm{~g}$ for chironomids) of the cores were prepared for palaeoecological analysis following standard protocols (Faegri and Iversen 1989; Brooks et al. 2007); see Matthews-Bird et al. (2017) for full details. Palaeoecological data were plotted based on ecological groups formed on the basis of functional types and/or ecological indicator value (pollen), and on synchronous occurrence of maximum values (chironomids) (see for details Tables S4, S5 and S6). For the Andean pollen data (L. Baños), an extra category for tree pollen (called longdistance forest) was established to differentiate pollen grains arriving by wind dispersion from outside the landscape (regional input), following previous research standards (Hagemans et al. 2019; Moscol-Olivera et al. 2009; Rull 2006).

The isotope composition of 11 (L. Baños) and 19 (L. Pindo) decalcified sample residues was determined at 
Fig. 2 Time slices of the ecological dynamics shown by partial communities of Lagunas Baños and Pindo during the last 2000 years. $\mathrm{C} / \mathrm{N}$ values refer to atomic ratios. Note the differences in the $\mathrm{Y}$ axis scale for the stable isotopes measurements (panels a and $b$ ). $X$ axes in all figures are the specific estimated age for each sample (time slice) expressed in the Common Era (CE), calculated through the age depth models shown in the Supplementary material (Figs. S1 and S2). Please note that the $\mathrm{X}$ axes are not linear due to variations in the age-depth models (changes in the sedimentation rate of the deposits through time). Dashed lines represent the moment of the volcanic event (tephra deposition in the lake catchment), being double in Laguna Baños (original and secondary). Taxa included for defining pollen and chironomids' assemblages are listed in Tables $\mathrm{S} 3$, S4 and S5
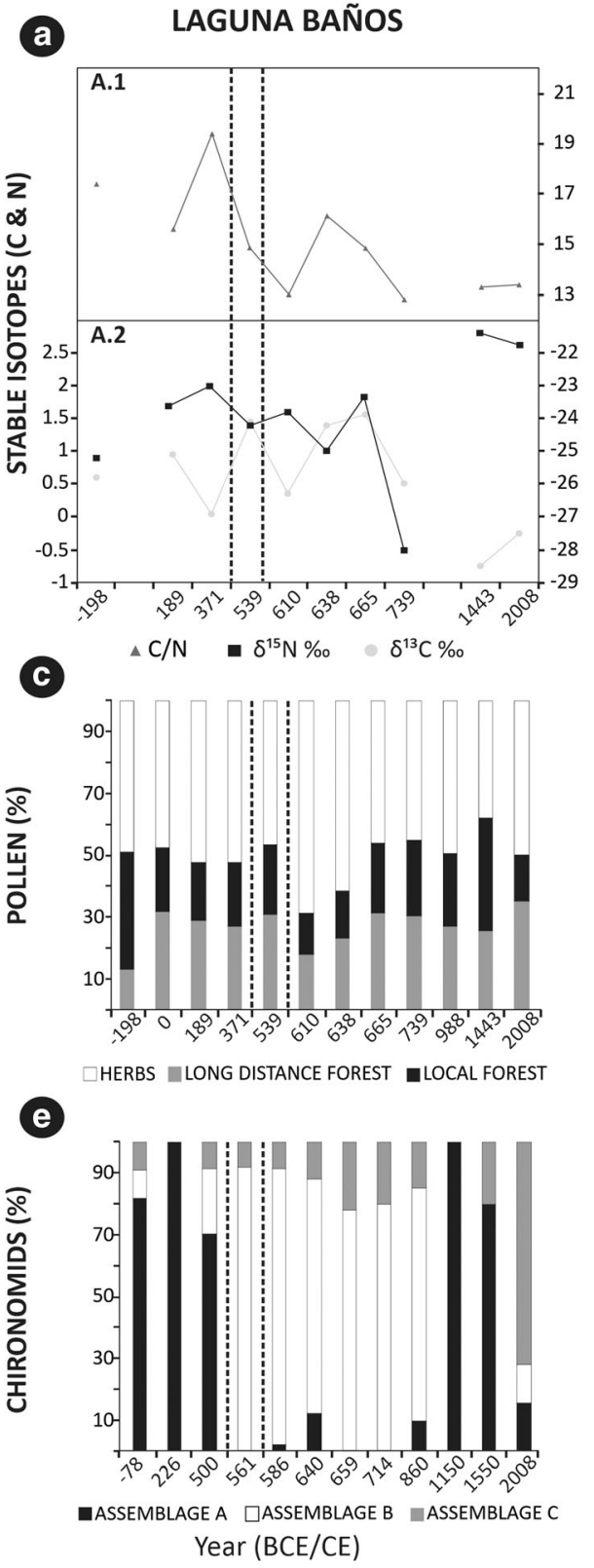

LAGUNA PINDO
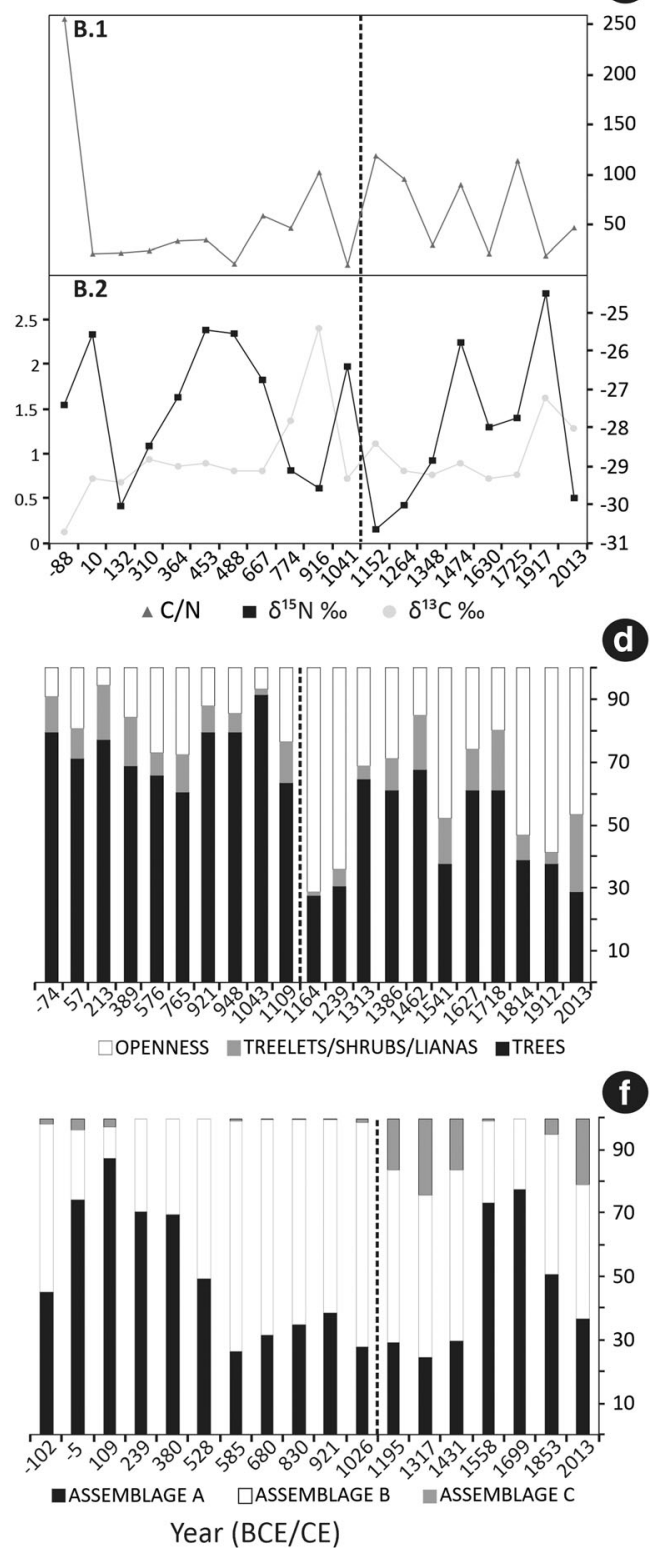

approximately $10 \mathrm{~cm}$ intervals (at a multi-centennial resolution for L. Baños and of c. 100 years for Pindo). Briefly, $\sim 0.6 \mathrm{~g}$ sample aliquots were homogenized and treated sequentially with $0.1 \mathrm{~m}$ and $1 \mathrm{~m} \mathrm{HCl}$ for $24 \mathrm{~h}$, before being rinsed to neutrality with Milli-Q water $(18.2 \mathrm{M} \Omega . \mathrm{cm})$. The isotopic composition $\left(\delta^{13} \mathrm{C}\right.$ and $\left.\delta^{15} \mathrm{~N}\right)$ of the dried re-homogenized residues was then determined using a Thermo Flash HT elemental analyser equipped with a Thermo zero-blank device coupled to a Thermo MAT 253 mass spectrometer (EA-MS). Data are expressed following the guidelines for the reporting of stable isotope measurement results (Coplen 2011).

We have applied the approach proposed by Cole et al. (2014) to estimate the recovery rates $\left(\mathrm{RR}^{1}\right)$ and declines $\left(\mathrm{D}^{2}\right)$ observed in the communities after the disturbance event.
Those estimates are based on the following equations and for the purposes of this study have been slightly modified:

$$
\begin{aligned}
& \mathrm{RR}=(((\text { Cmax }- \text { Cmin }) /(\text { Cpre-Cmin })) * 100) / \text { Trec } \\
& \mathrm{D}=((\text { Cpre-Cmin }) * 100) / \text { Cpre }
\end{aligned}
$$

Where Cpre is the abundance expressed in \% of the community under study before the volcanic event. $\mathrm{Cmin}$ is the \% just after the event, that is, the first post-tephra sample. Cmax is the abundance of the community after the event, at its maximum recovery; and Trec is the minimum time required since the event shift until the recovery (years from Cmin to Cmax).

Statistical analyses aimed to determine the compositional change between samples were performed in $\mathrm{R}$ version 3.82 ( $\mathrm{R}$ 
Core Development Team 2015): (i) Detrended Correspondence Analysis (DCA) was performed using the package 'vegan' version 2.3-5 (Oksanen et al. 2013); (ii) Rates of Change (RoC) between contiguous samples were calculated using the package 'rioja' (Juggins 2017); and (iii) Chord distance dissimilarity coefficient between samples previous and after the disturbance (Overpeck et al. 1985; Payne and Egan 2019) was calculated using the 'analogue' package (Simpson 2007). For these analyses, the dataset used was the percentage data after square root transformation and down weight of rare taxa.

\section{Results}

\section{Terrestrial community: vegetation}

Pollen samples in L. Baños are characterised by high abundances of Herbs $(\sim 50 \%)$ throughout the last 2000 years, although some variations can be observed (Fig. 2c). The oldest sample, around $198 \mathrm{BCE}$ (2148 cal yr BP), is marked by the highest (38\%) and lowest (13\%) abundances of Local and Long-Distance Forest taxa respectively. The samples immediately previous to the volcanic ash deposit are characterised by stable values of Herbs ( $\sim 50 \%)$, and a higher input from LongDistance Forest pollen taxa $(\sim 30 \%)$. The sample embedded between the two tephra layers shows a decrease in Herbs abundance (from 50 to $47 \%$ ); a concomitant change is also observed in the stable isotopes data (increase in $\delta^{13} \mathrm{C}$ and decrease in $\mathrm{C} / \mathrm{N}$ ratio (Fig. 2a)) and a higher input from Long-Distance Forest taxa (31\%). The first two post-tephra samples are characterised by an increase in Herbs (68 and $62 \%)$ and decrease of both Local (14-15\%) and LongDistance (18-23\%) Forest taxa abundances. Pre-tephra values are attained around $665 \mathrm{CE}$ (Fig. 2c), although with lower values in stable isotopes (Fig. 2a). Around $1443 \mathrm{CE}$, Herbs attain their lowest abundance in the entire sequence (38\%), and there is an increase in Local Forest (37\%). The uppermost (youngest) sample is characterised by average values for Herbs (around 50\%) and low abundance of Local Forest (15\%) comparable with the values obtained just after the second tephra deposition.

Laguna Pindo pollen data show that Trees dominate the assemblage prior the volcanic ash deposition (60-92\%; Fig. $2 \mathrm{~d}$ ), whilst other ligneous components included in the assemblage (Treelets/Shrublands/Lianas) make only a minor contribution to the pollen sum during this interval. Pre-tephra Openness assemblage values are very variable (6-28\%; Fig. 2d). The first two post-tephra samples (c. $1100 \mathrm{CE}$ ) are characterised by a large increase in Openness (71 and 64\%) and low abundances of Trees (27 and 31\%) that last around 200 years. The following samples show an increase in the Trees assemblage, with values around 60\%, and Openness indicators below $31 \%$. However, the dynamics of the three ecological groups during the samples spanning the interval between 1313 and $1718 \mathrm{CE}$ are more variable after the tephra than those observed before. Thus, Trees abundance ranges between 68 (at $1462 \mathrm{CE}$ ) and 37\% (at $1540 \mathrm{CE}$ ), Treelets/ Shrubs/Lianas between 4 and 19\%, and Openness between 15 and $48 \%$. The youngest samples are marked again by a decrease of Trees abundance (around 38\%) at the expenses of the Openness assemblage ( $>53 \%)$. The abundance in Openness taxa is reduced in the uppermost (youngest: 2013 CE) sample due to an increase in Treelets/Shrubs/Lianas up to $25 \%$.

The DCAs show the ordination of the samples based on the pollen abundance (Fig. 3). The pollen data from L. Baños are widely spread along Axis 1 of the DCA without a clear differentiation in their distribution between the samples pre- and post-volcanic event (Fig. 3a), and the variance in the rate of change is low (mostly below 0.01 ; Fig. 4). Only one sample is related to the negative values of Axis 2; this sample is the oldest of the sequence and is characterised by the highest and lowest abundances of local and extra-local forest taxa respectively (Fig. 2c). Contrarily, pollen samples of L. Pindo are more spread on the space defined by the two first axes, and post-tephra samples are clustered altogether along the upper side of Axis 2, whereas pre-tephra samples lie mostly in the positive side of Axis 1 (Fig. 3b). Four samples prior to the volcanic ash deposit in L. Pindo differ from the rest due to the sporadic presence of forest taxa only during a short interval (from c. 900 to $1100 \mathrm{CE}$ ), which results for an isolated sample (1043 CE) in a high RoC (Fig. 4).

\section{Aquatic community: chironomids}

The L. Baños' chironomid community is characterised by high abundances of Assemblage A (80-100\%), with minor contributions of Assemblages B and C for the samples prior the volcanic event (Fig. 2e). After the first tephra deposition, Assemblage A completely disappears, and $80 \%$ of the community is formed by Assemblage B. High abundances of Assemblage B are shown in the samples up to $860 \mathrm{CE}$, with minor and sporadic contributions from Assemblages $\mathrm{C}$ and $\mathrm{A}$. The samples between 1150 and $1500 \mathrm{CE}$ include very low concentrations of chironomid larval head capsules, and so are unreliable in providing a representative sample of the chironomid fauna (Matthews-Bird et al. 2017), but the capsules preserved show taxa components of Assemblage A. The uppermost (youngest) sample $(2008 \mathrm{CE})$ is characterised by a high abundance $(72 \%)$ of Assemblage $\mathrm{C}$, whereas Assemblages A and B show low values (15 and 13\% respectively).

The chironomid community of L. Pindo is characterised at the beginning of the sequence (102 BCE, $2052 \mathrm{cal} \mathrm{yr} \mathrm{BP)} \mathrm{by}$ high abundances of Assemblages $\mathrm{A}$ and $\mathrm{B}$, with a minor 
Fig. 3 Biplot of the DCA analyses performed on pollen and chironomid data at Lagunas Baños and Pindo. For the statistical analysis, percentage data (of individual taxa, not grouped by assemblages) were used. Black (filled) and white (empty) dots represent pre- and post-tephra samples respectively, whereas the upper (youngest) sample has been plotted in grey for each dataset. In panel 3c (chironomids of Laguna Baños), samples represented with dashed lines show very low counts (Matthews-Bird and others 2017) preventing an accurate ordination based on taxa composition

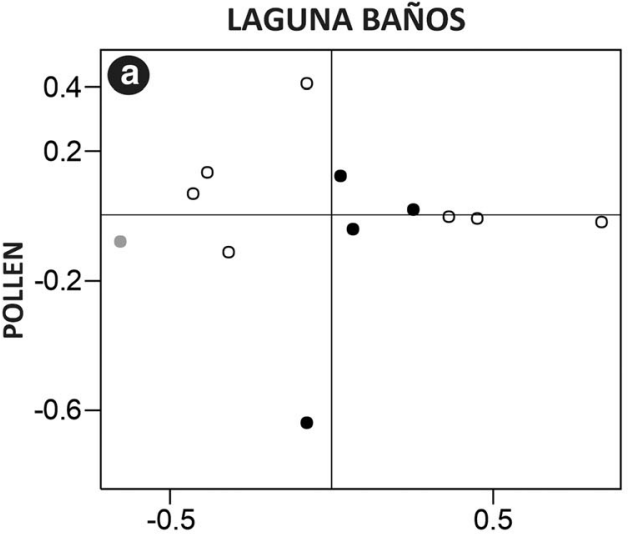

LAGUNA PINDO
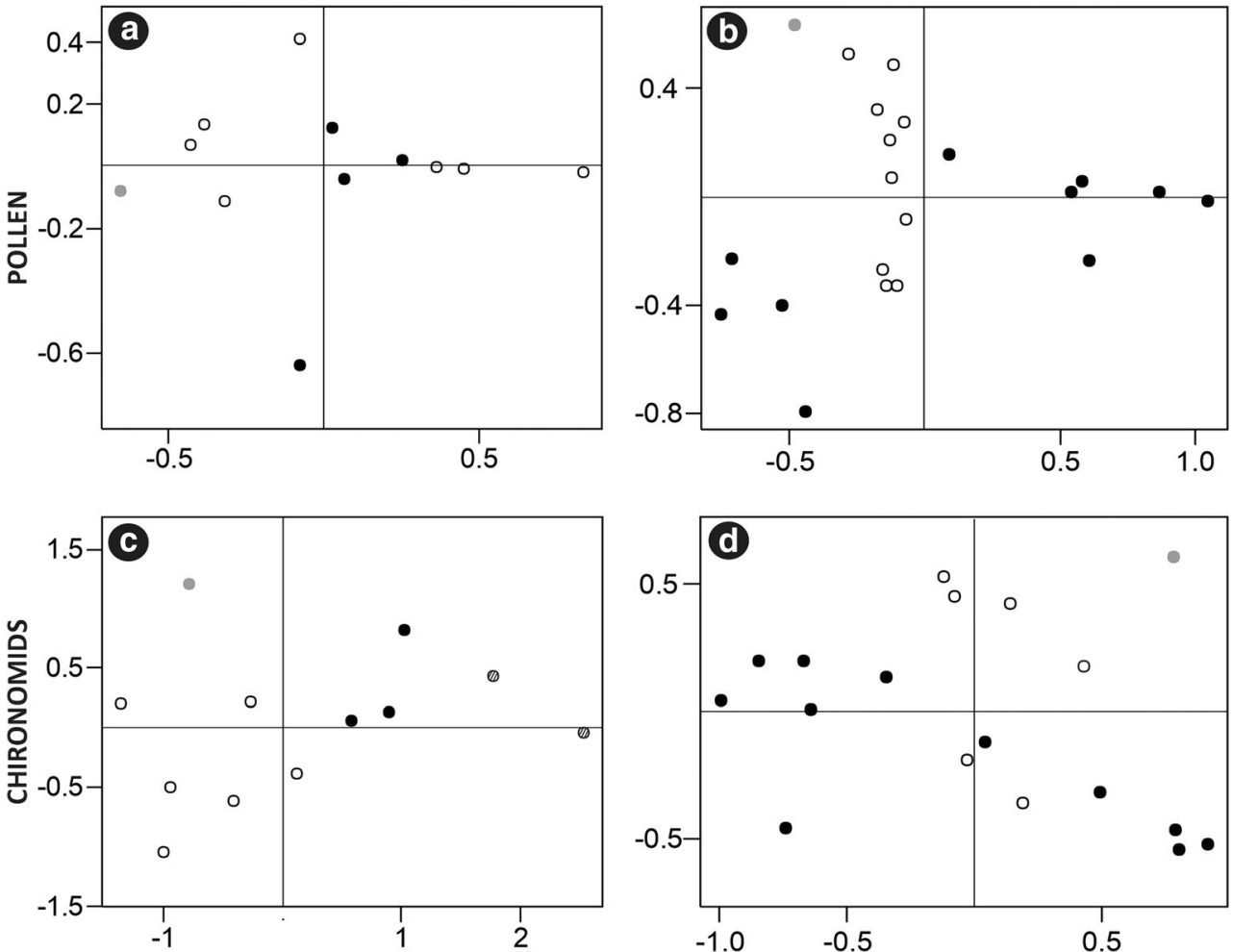

contribution (2\%) from Assemblage C (Fig. 2f). During the following samples (from $5 \mathrm{BCE}$ to $528 \mathrm{CE}$ ), the community shows high values (49-88\%) of Assemblage A. These high values of Assemblage A see a decrease in abundance (between 26 and 38\%), and are replaced by high values (61$72 \%$ ) of Assemblage B from 585 to 1026 CE. Low values of Assemblage A also characterise the first samples after the volcanic event, as the abundance of Assemblage B declines whereas Assemblage $\mathrm{C}$ increases (17-25\%). At $1558 \mathrm{CE}$, Assemblage A values show an increase up to $73 \%$, with a reduction in Assemblage $\mathrm{B}$ values and the almost disappearance of Assemblage C. The uppermost two samples are characterised by a decreasing trend in Assemblage A values and an increase up to $44 \%$ abundance of Assemblage B. The modern sample is also characterised by an increase to $21 \%$ of Assemblage $\mathrm{C}$.

The ordination analysis (Fig. 3c) of L. Baños shows a clear distribution of samples along Axis 1, with the pre-tephra deposition samples located on the right (positive) side, and the post-tephra samples situated to the left (negative axis). Two post-tephra samples are located to the right of Axis 1, but these are the samples containing low head capsule concentrations and so are unreliable. The modern sample is located at the upper left corner, showing the highest (positive) values for Axis 2, whereas the other post-tephra samples are located close to zero or at the negative side of the axis. Chironomid samples from L. Pindo are distributed more evenly through the entire DCA biplot space (Fig. 3d), particularly the pretephra samples, whereas post-tephra samples are clustered around positive or close to zero values on Axis 1. Regarding Axis 2, there is a clearer differentiation of the sample distribution, with most pre-tephra samples lying close to zero or on the negative side, and most post-tephra samples located on the positive side of the axis. Similar to L. Baños, the modern sample is located far from the rest of the sequence, this time at the upper right corner of the biplot.

\section{Discussion}

\section{Community dynamics and responses to volcanic depositions}

\section{Terrestrial community}

The vegetation around L. Baños has been characterised by an open landscape dominated by Andean herbs (mostly Poaceae) for at least the last 2000 years (Fig. 2c); although there is evidence of a constant background input of pollen from taxa located extra-locally (pollen arriving by E-W upwards wind dispersion from taxa located in lower elevations) (Hagemans et al. 2019; Moscol-Olivera et al. 2009; Rull 2006). The local dominance of $\mathrm{C}_{4}$ plants is also shown in the values obtained for the isotopes, with $\delta^{13} \mathrm{C}$ ranging between -27 and $-24 \%$, 
Fig. 4 Analyses of compositional change between samples. (a)

Compositional turnover based on Rates of Change (RoC) of Laguna Baños terrestrial (green) and aquatic (yellow) communities.

Vertical dashed lines represent the tephra deposits. (b)

Compositional turnover based on Rates of Change (RoC) of Laguna Pindo terrestrial (blue) and aquatic (orange) communities.

Vertical dashed line represents the tephra deposit. (c) Biplot showing the chord distance coefficient measuring similarity between post-disturbance samples compared to the last sample previous the volcanic ash deposition (Cpre). Samples organised according to the distance to the disturbance event (distance $0=$ disturbance event occurrence), from left (closer to the event) to right (farer from the event). The horizontal dotted black line represents the 5th percentile cut-off value of 0.48 , below which there is insignificant assemblage change between samples
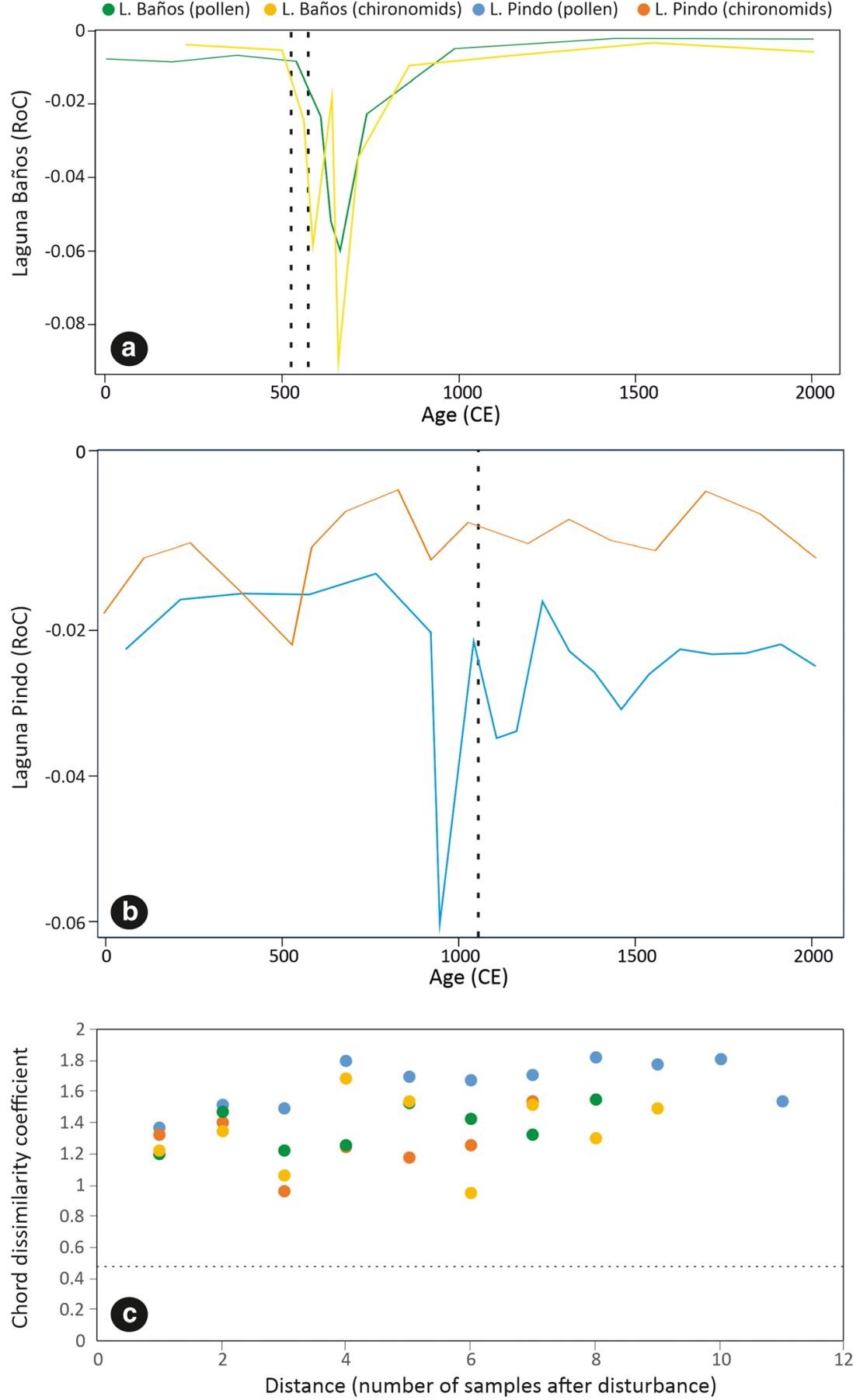

whereas the low values of $\mathrm{C} / \mathrm{N}(<20)$ highlight the contribution of the aquatic flora to the system (Fig. 2a) (Meyers 1994; Leng et al. 2006). The most visible change produced in the vegetation community appears just after the tephra deposition, with an increase in herb abundance that is equivalent to a local forest decline (D) of 38.6\% (Table 1). Long-distance (regional) forest also showed a synchronous decline. The three vegetation ecological groups return to pre-eruption values $\mathrm{c}$. 100 years after the event ( $665 \mathrm{CE})$, with a Recovery Rate (RR) of 1.9 (Table 1). The modern sample is however marked by a further increase in herbs and a decrease in local forest taxa. The results suggest that the vegetation community around L. Baños responded to the volcanic event as a short-lived impact by an expansion of grasslands concomitant with a subtle reduction of the forest, which rapidly ( $<100$ years) came back to pre-volcanic states.

Laguna Pindo has a completely different vegetation compared to L. Baños, and is characterised by a closed canopy forest vegetation around the lake to the shoreline (Fig. 1c). The local forest vegetation is reflected in the $\mathrm{C} / \mathrm{N}(>20)$ and 
Table 1 Recovery rates and declines of the communities studied at both locations after the volcanic ash event, following Cole et al. (2014)

\begin{tabular}{|c|c|c|c|c|c|c|}
\hline $\begin{array}{l}\text { Dominant } \\
\text { community }\end{array}$ & $\begin{array}{l}\text { Sample Pre } \\
\text { (Cpre) }\end{array}$ & $\begin{array}{l}\text { Sample Min } \\
\text { (Cmin) }\end{array}$ & $\begin{array}{l}\text { Sample Post } \\
\text { (Cmax) }\end{array}$ & Trec & $\begin{array}{l}\text { Decline } \\
\text { (D) }\end{array}$ & $\begin{array}{l}\text { Recovery rate } \\
\text { (RR) }\end{array}$ \\
\hline Forest Baños & $539(0.22)$ & $610(0.14)$ & $665(0.23)$ & 55 & 38.6 & 1.9 \\
\hline Forest Pindo & $1109(0.37)$ & $1164(0.11)$ & $1313(0.54)$ & 149 & 43.3 & 1.4 \\
\hline $\begin{array}{l}\text { Chironomids } \\
\text { Baños }\end{array}$ & $500(0.7)$ & $561(0)$ & NA & NA & 100 & NA \\
\hline $\begin{array}{l}\text { Chironomids } \\
\text { Pindo }\end{array}$ & $1026(.71)$ & $1195(0.54)$ & NA & NA & 23.8 & NA \\
\hline
\end{tabular}

Sample columns (Pre: prior the event; Min: right after the event, contains the minimum values; and Post: sample after the event showing some degree of recovery) contain the age (in CE) and in brackets is shown the relative abundance (percentage) of the community under study. Calculations of RR for the chironomids community of L. Baños were not possible due to the regime shift and non-return of pre-disturbance assemblages. RR related to the chironomid community from L. Pindo could not be further calculated either as the dominant community before the volcanic event (Assemblage B) although present, did not attain higher values than $\mathrm{Cmin}$ in any of the post-ash deposition samples (Figs. 3 and 4). Trec: Recovery time (Cmax-Cmin). NA: Not applicable $\delta^{13} \mathrm{C}(-27$ to $-30 \%$ o values, which indicate a major role for terrestrial $\mathrm{C}_{3}$ plant input in the sedimentary organic matter (Fig. 2b) (Meyers 1994). Forest taxa dominate the pollen assemblage prior to the volcanic event; although minor variations are observed in other ligneous taxa (Treelets/Shrubs/ Lianas; Fig. 2d). Immediately after the volcanic event, the vegetation community structure was very different, with an increase in Openness (taxa indicative of perturbation by some sort of clearing or canopy opening: Cecropia sp., Poaceae and Spermacoce sp.; Table S5) and a marked decrease in both categories of ligneous taxa with a D in Trees of $43.3 \%$ (Table 1). The following stages of the vegetation were characterised by an increase in Tree taxa eventually attaining values similar to those prior to the event $(\mathrm{RR}=1.4)$, but only briefly. Thus, the last 500 years have been marked by a more variable and dynamic trend of the vegetation with a higher contribution of Openness components. The increase in Treelets/Shrubs/Lianas (non-tree ligneous taxa) in the uppermost (youngest) sample may be indicative of some restructuring of the forest canopy. The higher dynamism during the last 2000 years of the vegetation surrounding L. Pindo compared to L. Baños can be also observed in the DCAs, with the samples distributed more evenly along the two main axes (Fig. 3b). The increase in forest cover prior the volcanic event could be due to the natural response of this dynamic forest to an environmental driver (although not temperature-driven; Matthews-Bird et al. 2016). The volcanic ash deposit caused the L. Pindo vegetation community to experience forest clearance and a resulting increase in the openness of the community that required around 150 years to revert back to similar pre-volcanic forest values. However, the disturbance (alone or combined with other drivers), may have triggered some instability in the vegetation community, as changes in forest cover have been more dynamic since the tephra was deposited (Figs. $2 b, 2 d$ and 4$)$.

\section{Aquatic community}

Laguna Baños shows a dramatic change between the dominant chironomid assemblages before and after the volcanic ash deposit (Fig. 2e; Matthews-Bird et al. 2017), with D = $100 \%$ (Table 1). The shift in the dominance to this new assemblage (Assemblage B) remains for more than 300 years. However, the previous community does not reappear afterwards, so RR could not be calculated and the change can be considered a regime shift. Figure 2e shows two samples (at 1150 and $1550 \mathrm{CE}$ ) with a similar composition to pre-volcanic samples (located in Fig. 3c at the positive end of Axis 1), but the concentration of chironomid remains found in these samples was very low (less than 5 head capsules/gramme; Matthews-Bird et al. 2017) and so is unreliable. The modern sample is characterised by a new assemblage, different from those dominant just before and after the tephra deposition (Fig. 3c). The consequences of the volcanic event for the aquatic community of L. Baños are the largest of the study, showing a complete regime shift of the chironomid community that has not recovered until the present-day.

The dynamics observed in the chironomid community of L. Pindo do not follow the patterns observed in L. Baños. At the beginning of the sequence, there is a shift in the dominant community around $500 \mathrm{CE}$, with Assemblage A being replaced by Assemblage B. Some responses to the ash deposition could be inferred, as the abundance of the dominant prevolcanic assemblage (Assemblage B) slightly decreases in the samples after the tephra deposition. As Cmin is higher than subsequent consecutive samples, RR cannot be calculated. However, although after the ash deposit Assemblage C appears in the system (causing the decrease of Assemblage B), the former assemblages (A and B) do not disappear but remain dominant for more than 300 years (Fig. 2f), with a D of $23.8 \%$ (Table 1). Moreover, around $1550 \mathrm{CE}$, Assemblage A shifts to 
replace Assemblage $B$ as dominant, showing similar values as the samples 2000 years previously. Thus, based on the composition, there is not a clear difference between samples prior to and after the tephra deposition (Fig. 3d). In addition, RoC shows that the dynamism of the chironomid community has been higher during the period prior to the volcanic event than afterwards (Fig. 4), indicating the response to other environmental drivers (see also Matthews-Bird et al. 2017). As in the case of L. Baños, the most different sample of the last two millennia of L. Pindo is the modern sample, which is located at the upper right corner of the DCA plot, due to the presence of taxa not found in former samples (Fig. 3d). Based on our results, there is not enough evidence for linking the posttephra chironomid community dynamics observed in L. Pindo with the ash deposit.

\section{Communities' interactions and cascade effects}

The incoming volcanic ash to L. Baños c. $520 \mathrm{CE}$ impacted both terrestrial and aquatic communities, but to differing degrees (Figs. 1b and 5). Following the volcanic event, the terrestrial vegetation showed a slight shift in the herbaceous vegetation community, with a recovery to the previous state in less than 100 years. This rate of recovery is in agreement with other, non-tropical locations, where volcanic impacts have been shown to heavily disturb open vegetation (non-arboreal pollen), but in short-time scales (sub-centennial) (Long et al. 2014; Allen and Huntley 2018). In contrast, the aquatic community at L. Baños experienced a regime shift following the volcanic event. The dominant components of the chironomid assemblages changed from Polypedilum nubifer-type and Pseudochironomus to Cricotopus/Paratrichocladius type II and Corynoneura cf. coronara-type (Table S6; MatthewsBird et al. 2017). Furthermore, the change appears to have been permanent, as there is still no sign of a return of the pre-volcanic event community today, some 1500 years after the tephra deposition. Interestingly, there is a difference in the speed of response of the terrestrial and aquatic communities to the double tephra deposition. The subtle shift in the terrestrial vegetation is recorded only after the second tephra deposit (Fig. 2c), suggesting that the origin of the second ash deposit was due to soil instability and/or nearby slope collapse, and not by water, rejecting the second hypothesis postulated in Matthews-Bird et al. (2017). On the contrary, the dramatic shift in the chironomid community occurred immediately after the first tephra deposit (Fig. 2d). The immediate impact of the tephra on the aquatic community is also clear in the stable isotope data (Fig. 2a), where a decrease in lake primary productivity linked to the $\mathrm{N}$ values is notable just after the first ash deposition. The relatively higher sensitivity of aquatic communities to the first tephra deposition shown in the chironomid data is also mirrored in the aquatic and littoral flora, which also showed a marked compositional change (Matthews-Bird et al. 2017). Matthews-Bird et al. (2017) argued that the thickness of the tephra deposited in L. Baños played a key role in the responses of the aquatic community.

The impact of the tephra deposition detected in L. Pindo 1130 years ago had a more severe effect on the vegetation community than on the aquatic community. Following the tephra deposition, a period of around 150 years passed before the forest structure was able to re-establish at the site. Furthermore, despite the forest recovery, the post-tephra deposition vegetation community differs from that of the preceding forest (Figs. 3b and 4). The post-tephra terrestrial vegetation succession experienced an initial stage dominated by Openness, then an increase in forest taxa abundance with higher contribution of non-tree ligneous taxa (Treelets/ Shrubs/Lianas), and finally a further decrease in forest (showed primarily by low values of Trees) during the last 200 years (Fig. 2d). A similar succession pattern has been also suggested for a nearby montane location in Ecuador (Lake Huila) following human (as opposed to volcanic) activities, with a similar recovery rate (130 years; Loughlin et al. 2018). However, the time interval required for the recovery of these forest structures in Pindo and Huila is faster than for those reviewed in Cole et al. (2014), with an average recovery time of 325 years for South American forests. Our study agrees however with Cole et al. (2014), which suggested that RR are normally faster for large, infrequent perturbations such as volcanic activities. The tephra deposition also had a negative effect in the source of organic matter and primary productivity of the lake, as shown by the stable isotope curves and the decrease in $\mathrm{N}$ (Fig. 2b). However, despite the major change in the terrestrial environment immediately around the lake, there is no a major change observed in the aquatic chironomid community attributable to this deposition (Fig. 2f).

Based on the differences between the terrestrial vegetation and the responses in the aquatic communities of both study sites, we suggest that the natural barrier that the forest vegetation forms plays a key role in reducing the amount of ash entering the aquatic system (Sakals et al. 2006). In both locations, other drivers for the communities' changes may have played a role in combination with the volcanic event, such as climatic shifts or human activities. An example of the sensitivity of the systems to other drivers is provided in the vegetation record of L. Pindo, where an increase in Trees is observed prior the tephra (Fig. 2d). However, we suggest that even if other environmental drivers were involved at the time of the volcanic event, the ash deposition was determinant in explaining the changes observed based on: (i) the synchronicity of the changes in the communities with the volcanic ash deposition, that occurred at different times in both locations; and (ii) the lack of climatic dynamics change in the region (Flantua et al. 2016) and human impact evidence in the sites (lack of cultivars and no/low values of charcoal particles found in the sedimentary archives, data not included) or 
Fig. 5 Cartoon sketch of a treeless (left) and a forested (right) landscape responding to a volcanic-induced ash deposition, representing the pre-disturbance (top), disturbance (middle) and post-disturbance (bottom) stages. Volcanic ash has been drawn in orange to increase visibility. Arrows represent the potential runoff, with differential thickness related to the potential intensity. The main effect of the volcanic deposition in the treeless landscape is manifested here by a minimal impact on the terrestrial vegetation and a thick tephra being deposited in the submerged basin of the aquatic community (lake bed), likely due to runoff. On the contrary, the forested landscape is marked by a large impact on the terrestrial ecosystem, with an increased openness in the canopy (tree cover) and a thinner tephra due to lower runoff (related to forest-driven soil stability). Draw not to scale
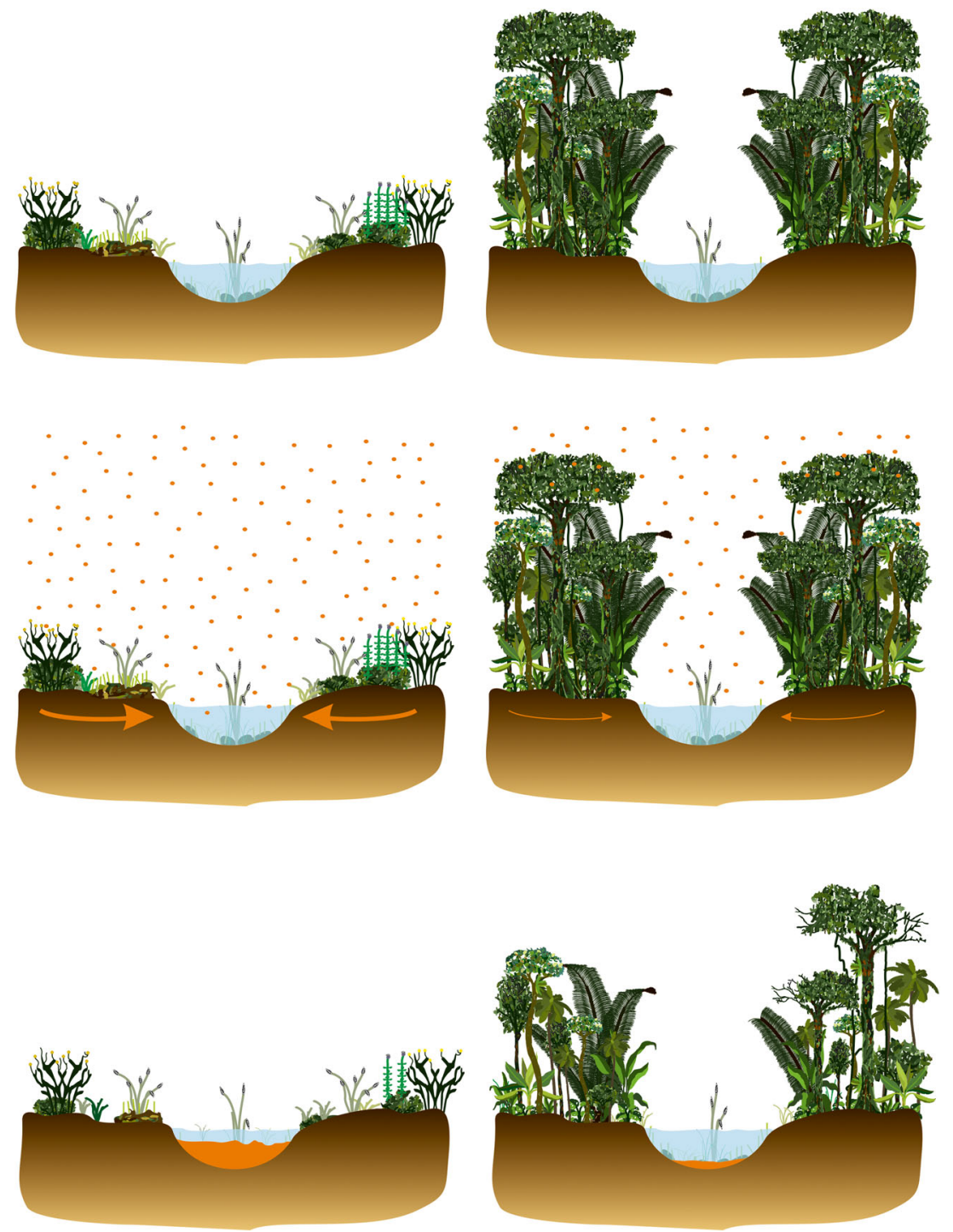

sequences nearby (Ledru et al. 2013) coeval to the communities' changes. Nevertheless, human activities have been found in sequences near L. Baños although at lower elevations (Loughlin et al. 2018; McMichael et al. 2021), as well as archaeological sites near L. Pindo (Rostain et al. 2014), so more specific analyses for completely ruling out the human influence in these two lakes should be addressed in the future.

In our simple model, the effect of a volcanic ash deposition on the aquatic communities in a forested landscape can be anticipated to be lower compared to an exposed or treeless landscape (Fig. 5). This difference is because the entry of ash into the aquatic system is limited in two ways: (i) air fall is reduced as windspeeds are slowed down by the surrounding vegetation, and (ii) surface wash is reduced because necromass, trunks and roots prevent slope wash and allow sediment focusing and reducing lower run-off (Self et al. 2015; Eddodóttir et al. 2017). Conversely, open landscapes with high levels of surface waterflow can make aquatic communities more vulnerable because there is no buffering by vegetation, and, in the case of $L$. Baños, susceptible to a double impact through the secondary mobilisation and redeposition of material into lakes (Paine et al. 1998). In addition to the enhanced threat to ecosystems that deforestation poses, it is also important to note that much of the water resource of Andean communities is collected in reservoirs within the landscapes which surrounds L. Baños; indeed within the Cayambé Coca National Park (also locally known as the 'Park of the Water'), in which L. Baños is situated, there are around 80 glacially formed reservoirs.

\section{Long-term ecological data for restoration and management}

The buffer effect of forest vegetation to aquatic communities is essential for ecosystems, as it reduces the magnitude of the impact and thus prevents further cascade effects. From an 
economic perspective, this is particularly important in those locations responsible for large ecosystems services, such as the Cayambé Coca National Park, which provides the water supply to Quito and surrounding districts, home to more than 1.5 million people (Echavarría and Lochman 1998). Such ecosystems have been highlighted as vulnerable due to additional external stressors, such as climate change and glacier retreat, which could affect their water storage capacity (Ledru et al. 2013; Cuesta et al. 2019). The present study has highlighted the key role of a well-developed plant community to not only mitigate the immediate effects of volcanic tephra deposition, but also the rate of ecosystem recovery (Ágústsdóttir 2015). Based on our results, we suggest that conservation of the remaining forest patches and reforestation where needed with native species should be encouraged to increase soil stability (to decrease erosion and landslides) and decrease the landscape openness, at least in locations close to water resources (Swetnan et al. 1999; Cuesta et al. 2017). Such initiatives have already been highlighted by previous authors to be included routinely in national or supra-national Disaster Risk Reduction (DRR) plans (Ágústsdóttir 2015), which in addition will help to reduce the alarming deforestation rates in neotropical forests and its consequences (i.e. C sequestration, climate change feedbacks, global biodiversity loss) (Pan et al. 2011; Spracklen et al. 2012; Alroy 2017).

The higher plant diversity of L. Pindo mid-elevation forest compared to the high Andean site (L. Baños; Tables S4 and S5) may also have had an influence on the type of ecosystem response, which could result in a higher resilience or stability to the disturbance in the long-term (Adolf et al. 2020; Behling 2000; Mori et al. 2013). As such, although the structure of the community reverts to pre-disturbance values, the analysis based on taxa composition has shown the high dissimilarity between samples pre- and post-ash deposition (Figs. 3 and 4). The mid-elevation seedling pool characteristic of these megadiverse environments could have been a key factor for the rapid response of the plant community compared to the 325 years on average registered for South American records (Cole et al. 2014). The particular conditions of this location could have helped in securing some of the ecosystem services previously provided (like the soils stability) despite a change in the forest composition (Figs. 3, 4 and 5) (Loughlin et al. 2018). Our analysis of forested versus deforested landscape responses can be considered an analogue for studying the consequences of forest loss, which has been suggested as a catalyst for population and biodiversity changes, and increased vulnerability of ecosystems to degradation (Daskalova et al. 2020; McDowell et al. 2020). Regardless of the origin of the ecosystem resilience shown in L. Pindo compared to L. Baños, the consequences in potential cascade effects are clear. Thus, it can be seen that, although there is an effect on primary productivity due to the incoming ash, this perturbation does not extend to the consumers side of the trophic chain, i.e. the chironomid community. On the other hand, in L. Baños, the lack of protection by a surrounding forest facilitated a higher impact on the entire aquatic community (producers and consumers) and ecosystem (MatthewsBird et al. 2017), resulting in a regime shift to another stable state for more than 1500 years (Hodgson et al. 2015). Moreover, L. Baños is a connected catchment, which makes the aquatic communities behave as a metacommunity (Leibold et al. 2004). This connectivity could result in a higher sensitivity to a given disturbance even at local scales, and the occurrence of further cascade effects could be increased (Heino 2013).

Finally, the most different samples in all four organism datasets are the modern samples, including the dominance of chironomid taxa such as Chironomus anthracinus-type (Table S6; Matthews-Bird et al. 2017) and the increase in herbs or vegetation openness indicators (Figs. $2 \mathrm{c}$ and $2 \mathrm{~d}$ ). The occurrence of these taxa could reflect the influence of current anthropogenic activities in the surroundings. This change is intriguing as both locations are not under the influence of obvious anthropogenic impacts, as they are relatively isolated. However, activities such as the creation of the Biological Station in Pindo, with the consequent creation of the pathway to the lake, or the fishing and tourism activities in the Cayambé Coca National Park where L. Baños is located (rainbow trout-Oncorhynchus mykiss - was introduced in the high Andes at the beginning of the $20^{\text {th }}$ century; Moillet et al. 2018)), seem to have altered the systems. Contrary to the effect caused by tephras, there has not been any buffering or mitigation effect observed so far, and the impacts are clear in both terrestrial and aquatic communities. In this way, anthropogenic impacts are revealed as a potential major force of change and ecological degradation. It is therefore essential to improve awareness of human behaviour to impact and degrade ecosystems, in contrast to the impacts of natural events.

\section{Conclusions}

The ecological impacts of tephra deposition in the tropical Andes have been studied using long-term ecological datasets from a variety of proxies from terrestrial and aquatic communities and in two different environments. Palaeoecological analysis during the last 2000 years at L. Baños (Andean páramo) and L. Pindo (pre-montane forest) show different responses to volcanic events, particularly in reference to the differential impacts on the aquatic communities. Open terrestrial communities have shown a slight increase in herbs and a quick recovery to previous assemblages following volcanic ash deposition. However, the volcanic ash deposition in the aquatic system had dramatic consequences for the aquatic community, promoting a regime shift that has not reverted 1500 years after the event. On the other hand, closed terrestrial 
communities showed a marked effect due to the ash incoming, with the canopy opening and tree taxa abundance decreasing. In this ecosystem, no major changes in the aquatic community were observed resulting from the tephra deposition. We suggest that the forest acted as a protective barrier, preventing a large fallout of ash into the aquatic system. The forest in the pre-montane location not only acted as a buffer for ash falling into the water from the air, but also prevented landslides of tephra deposits by enhancing soil stability and decreasing potential erosion. Moreover, the large diversity of the premontane forest could have played a role in the quick recovery observed in the terrestrial community after the volcanic event compared to other South American records. The use of longterm data allowed comparison between community dynamics resulting from the volcanic event and those independent of this perturbation. These results showing community interactions and potential feedback also have implications for ecosystem-based management strategies. Forest conservation is perceived as an economically appealing nature-based solution for preserving important ecosystem services, such as water storage and quality. In this sense, the results also highlight additional negative consequences that the largely humandriven deforestation currently occurring in the tropics might cause. It has been shown that in order to adequately assess the dynamics of a response to a given perturbation, long-term before and after data are essential. Such data would also be required for developing further initiatives for restoration, which should be based on historical records and understanding the responses to impacts of native species.

Supplementary Information The online version contains supplementary material available at https://doi.org/10.1007/s10113-021-01783-1.

\begin{abstract}
Acknowledgements This study has been developed under the auspices of project FORSENS, funded by the Natural Environment Research Council (NERC) of UK (grant NE/J018562/1 to EM). Radiocarbon dating was supported by the NERC Radiocarbon Facility NRCF010001 (allocation number 1682.1112) awarded to FORSENS project by EM and performed by Pauline Gulliver. Field sampling was performed thanks to the required permits for research investigations provided by the Ecuadorian Ministry of Environment (ref. 14-2012-IC-FLO-DPAP-MA). Special thanks to Hayley Keen, Emily Sear, Mabs Gilmour and Simona Nicoara for the technical support, and Mark Bush and Iain Gilmour for their participation in the project. Patricia Mothes and Carmen Luzuriaga provided essential knowledge about the field locations, Susana León-Yánez assisted us with permission, and Joe Williams and Macarena Cárdenas helped WDG during the fieldwork of the Andean location. Two anonymous referees and editors Prof. Wolfgang Cramer and Dr Victor Resco de Dios helped to improve an earlier version of the manuscript.
\end{abstract}

Data availability Raw data is available in the National Geoscience Data Centre (NGDC), the repository linked to the funding agency (NERC) at https://www.bgs.ac.uk/services/ngdc/accessions/index.html? simpleText=NE/J018562/1
Open Access This article is licensed under a Creative Commons Attribution 4.0 International License, which permits use, sharing, adaptation, distribution and reproduction in any medium or format, as long as you give appropriate credit to the original author(s) and the source, provide a link to the Creative Commons licence, and indicate if changes were made. The images or other third party material in this article are included in the article's Creative Commons licence, unless indicated otherwise in a credit line to the material. If material is not included in the article's Creative Commons licence and your intended use is not permitted by statutory regulation or exceeds the permitted use, you will need to obtain permission directly from the copyright holder. To view a copy of this licence, visit http://creativecommons.org/licenses/by/4.0/.

\section{References}

Adolf C, Tovar C, Kühn N, Behling H, Berrío JC, et al (2020) Identifying drivers of forest resilience in longterm records from the Neotropics. Biol Lett 16:20200005. https://doi.org/10.1098/rsbl.2020.0005

Ágústsdóttir AM (2015) Ecosystem approach for natural hazard mitigation of volcanic tephra in Iceland: building resilience and sustainability. Nat Hazards 78:1669-1691. https://doi.org/10.1007/s11069015-1795-6

Allen JRM, Huntley B (2018) Effects of tephra falls on vegetation: a Late-Quaternary record from southern Italy. J Ecol 106:24562472. https://doi.org/10.1111/1365-2745.12998

Alroy J (2017) Effects of habitat disturbance on tropical forest biodiversity. Proc Natl Acad Sci U S A 114:6056-6061. https://doi.org/10. 1073/pnas.1611855114

Antos JA, Zobel DB (2005) Plant responses in forests of the tephra-fall zone. In: Dale V, Swanson F, Crisafulli C (eds) Ecological recovery of Mount St. Helens after the 1980 eruption. Springer, New York, NY, US, pp 47-58

Barberi F, Coltelli M, Ferrara G, Innocentii F, Navaro J, et al (1988) PlioQuaternary volcanism in Ecuador. Geol Mag 125:1-14. https://doi. org/10.1017/S0016756800009328

Behling H (2000) A 2860-year high-resolution pollen and charcoal record from the Cordillera de Talamanca in Panama: a history of human and volcanic forest disturbance. Holocene 10:387-393. https://doi. org/10.1191/095968300668797683

Blaauw M (2010) Methods and code for "classical" age-modelling of radiocarbon sequences. Quat Geochronol 5:512-518. https://doi. org/10.1016/j.quageo.2010.01.002

Brooks SJ, Langdon PG, Heiri O (2007) The identification and use of Palaearctic Chironomidae larvae in Palaeoecology, QRA Technical Guide No. 10, Quaternary Research Association, London.

Cole LES, Bhagwat SA, Willis KJ (2014) Recovery and resilience of tropical forests after disturbance. Nat Commun 5:3906. https://doi. org/10.1038/ncomms4906

Colinvaux PA, De Oliveira PE, Moreno JE (1999) Amazon pollen manual and atlas. Harwood Academic Publishers, Amsterdam

Coplen TB (2011) Guidelines and recommended terms for expression of stable-isotope-ratio and gas-ratio measurement results. Rapid Comm Mass Spectrom RCM 25:2538-2560. https://doi.org/10. 1002/rcm.5129

Cuesta F, Peralvo M, Merino-Viteri A, Bustamante M, Baquero F et al (2017) Priority areas for biodiversity conservation in mainland Ecuador. Neotrop Biodivers 3:93-106. https://doi.org/10.1080/ 23766808.2017.1295705

Cuesta F, Llambí LD, Huggel C, Drenkhan F, Gosling WD et al (2019) New land in the Neotropics: a review of biotic community, ecosystem, and landscape transformations in the face of climate and glacier 
change. Reg Environ Chang 19:1623-1642. https://doi.org/10. 1007/s10113-019-01499-3

Dale VH, Crisafulli CM, Swanson FJ (2005) 25 years of ecological change at Mount St. Helens Science 308:961-962. https://doi.org/ 10.1126/science. 1109684

Daskalova GN, Myers-Smith IH, Bjorkman AD, Blowes SA, Supp SR et al (2020) Landscape-scale forest loss as a catalyst of population and biodiversity change. Science 368:1341-1347. https://doi.org/ 10.1126/science.aba1289

del Moral R, Grishin SY (1999) Volcanic disturbances and ecosystem recover. In: Walker LR (ed) Ecosystems of disturbed ground: ecosystems of the world 16. New York, Elsevier, pp 137-160

Echavarría M, Lochman L (1998) Watershed conservation fund in Quito, Ecuador. Policy mechanisms for watershed conservation: case studies. Washington, D.C., TNC.

Eddodóttir SD, Erlendsson E, Gísladóttir G (2017) Effects of the Hekla 4 tephra on vegetation in Northwest Iceland. Veget Hist Archaeobot 26:389-402. https://doi.org/10.1007/s00334-017-0603-5

Faegri K, Iversen J (1989) (Fourth Edition by K. Faegri, P. E. Kaland, and K. Krzywinski). Textbook of pollen analysis. John Wiley \& Sons, New York, 328 p.

Flantua SGA, Hooghiemstra H, Vuille M, Carson JF, Gosling WD, et al (2016) Climate variability and human impact in South America during the last 200 years: synthesis and perspectives from pollen records. Clim Past 12:483-523. https://doi.org/10.5194/cp-12-4832016

Foster DR, Knight DH, Franklin JF (1998) Landscape patterns and legacies resulting from large, infrequent forest disturbances. Ecosystems 1:497-510. https://doi.org/10.1007/s100219900046

Hagemans K, Tóth C-D, Ormaza M, Gosling WD, Urrego DH et al (2019) Modern pollen-vegetation relationships along a steep temperature gradient in the Tropical Andes of Ecuador. Quat Res 19:113. https://doi.org/10.1017/qua.2019.4

Hall MD, Mothes PA (2010) New active rhyolitic eruption centers, eastern foot of the Ecuadorian Andes. Abstract, Cites on Volcanoes-6, Tenerife Spain. Session: 1.1-P-86.

Hall ML, Samaniego P, Le Pennec JL, Johnson JB (2008) Ecuadorian Andes volcanism: a review of Late Pliocene to present activity. J Volcanol Geotherm Res 176:1-6. https://doi.org/10.1016/j. jvolgeores.2008.06.012

Harling G (1979) The vegetation types of Ecuador - a brief survey. In: Larsen K, Holm-Nielsen LL (eds) Tropical Botany. Academic press, New York, pp 165-174

Haruki M, Tsuyuzaki S (2001) Woody plant establishment during the early stages of volcanic succession on Mount Usu, northern Japan. Ecol Res 16:451-457. https://doi.org/10.1046/j.1440-1703.2001. 00407.x

Heino J (2013) The importance of metacommunity ecology for environmental assessment research in the freshwater realm. Biol Rev 88: 166-178. https://doi.org/10.1111/j.1469-185X.2012.00244.x

Hijmans RJ, Cameron SE, Parra JL, Jones PG, Jarvis A (2005) Very high resolution interpolated climate surfaces for global land areas. Int $\mathrm{J}$ Climatol 25:1965-1978. https://doi.org/10.1002/joc.1276

Hodgson D, McDonald JL, Hosken DJ (2015) What do you mean, 'resilient'? Trends Ecol Evol 30:503-506. https://doi.org/10.1016/j. tree.2015.06.010

Hogg AG, Hua Q, Blackwell PG, Niu M, Buck CE et al (2013) SHCal13 Southern Hemisphere calibration, 0-50,000 years cal BP. Radiocarbon 55:1889-1903. https://doi.org/10.2458/azu_js_rc.55. 16783

Hotes S, Poschlod P, Takahashi H (2006) Effects of volcanic activity on mire development: case studies form Hokkaido, northern Japan. Holocene 16:561-573. https://doi.org/10.1191/0959683606hl952rp

Hughes PDM, Mallong G, Bronw A, Essex HJ, Stanford JD et al (2013) The impact of high tephra loading on late-Holocene carbon accumulation and vegetation succession in peatland communities. Quat
Sci Rev 67:160-175. https://doi.org/10.1016/j.quascirev.2013.01. 015

Jørgensen PM, León-Yánez S (eds) (1999) Catalogue of the vascular plants of Ecuador. Missouri Botanical Garden Press, St. Louis

Juggins S (2017) rioja: Analysis of quaternary science data, R package version (0.9-15). Available at: http://cran.r-project.org/package= rioja

Le Pennec JL, Jaya D, Samaniego P, Ramón P, Moreno Yánez S et al (2008) The AD 1300-1700 eruptive periods at Tungurahua volcano, Ecuador, revealed by historical narratives, stratigraphy and radiocarbon dating. J Volcanol Geotherm Res 176:70-81. https://doi.org/10. 1016/j.jvolgeores.2008.05.019

Ledru M-P, Jomelli V, Samaniego P, Vuille M, Hidalgo S et al (2013) The medieval climate anomaly and the Little Ice Age in the eastern Ecuadorian Andes. Clim Past 9:307-321. https://doi.org/10.5194/ cp-9-307-2013

Leibold MA, Holyoak M, Mouquet N, Amarasekare P, Chase JM et al (2004) The metacommunity concept: a framework for multi-scale community ecology. Ecol Lett 7:601-613. https://doi.org/10.1111/j. 1461-0248.2004.00608.x

Leng MJ, Lamb AL, Heaton THE, Marshall JD et al (2006) Isotopes in lake sediments. In: Leng MJ (ed) Developments in paleoenvironmental research, Isotopes in palaeoenvironmental research, vol 10. Springer, The Netherlands, pp 147-184

Livingstone DA (1955) A lightweight piston sampler for lake sediments. Ecology 36:137-139. https://doi.org/10.2307/1931439

Long CJ, Power MJ, Minckley TA, Hass AL (2014) The impact of Mt Mazama tephra deposition on forest vegetation in the Central Cascades, Oregon, USA. Holocene 24:503-511. https://doi.org/10. 1177/0959683613520258

Loughlin NJD, Gosling WD, Mothes P, Montoya E (2018) Ecological consequences of post-Columbian indigenous depopulation in the Andean-Amazonian corridor. Nat Ecol Evol 2:1233-1236. https:// doi.org/10.1038/s41559-018-0602-7

Matthews-Bird F, Brooks SJ, Holden PB, Montoya E, Gosling WD (2016) Inferring late-Holocene climate in the Ecuadorian Andes using a chironomid-based temperature inference model. Clim Past 12:1263-1280. https://doi.org/10.5194/cp-12-1263-2016

Matthews-Bird F, Brooks SJ, Gosling WD, Gulliver P, Mothes P et al (2017) Aquatic community response to volcanic eruptions on the Ecuadorian Andean flank: evidence from the palaeoecological record. J Paleolimnol 58:437-453. https://doi.org/10.1007/s10933017-0001-0

McDowell NG, Allen CD, Anderson-Teixeira K, Aukema BH, BondLamberty B et al (2020) Pervasive shifts in forest dynamics in a changing world. Science 368:eaaz9463. https://doi.org/10.1126/ science.aaz 9463

McMichael CNM, Witteveen NH, Scholz S, Zwier M, Prins MA, et al (2021) 30,000 years of landscape and vegetation dynamics in a midelevation Andean valley. Quat Sci Rev 258:106866. https://doi.org/ 10.1016/j.quascirev.2021.106866

Meyers PA (1994) Preservation of elemental and isotopic source identification of sedimentary organic matter. Chem Geol 114:289-302. https://doi.org/10.1016/0009-2541(94)90059-0

Millar CI, King JC, Westfall RD, Alden HA, Delany DL (2006) Late Holocene forest dynamics, volcanism, and climate change at Whitewing Mountain and San Joaquin Ridge, Mono Count, Sierra Nevada, CA, USA. Quat Res 66:273-287. https://doi.org/10.1016/j. yqres.2010.08.010

Mouillet C, Barta B, Espinosa R, Andino P, Christoffersen KS et al (2018) Ecological effects of introduced rainbow trout (Oncorhynchus mykiss) in pristine Ecuadorian high Andean lakes. Fundam Appl Limnol 191:323-337. https://doi.org/10.1127/fal/ 2018/1154

Montoya E, Keen HF, Luzuriaga CX, Gosling WD (2018) Long-term vegetation dynamics in a megadiverse hotspot: the ice-age record of 
a pre-montane forest of Central Ecuador. Front Plant Sci 9:196. https://doi.org/10.3389/fpls.2018.00196

Mori AS, Furukawa T, Sasaki T (2013) Response diversity determines the resilience of ecosystems to environmental change. Biol Rev 88: 349-364. https://doi.org/10.1111/brv.12004

Moscol-Olivera M, Duivenvoorden JF, Hooghiemstra H (2009) Pollen rain and pollen representation across a forest-páramo ecotone in northern Ecuador. Rev Palaebot Palynol 157:285-300. https://doi. org/10.1016/j.revpalbo.2009.05.008

Oksanen J, Guillaume Blanchet FRK, Legendre P, Minchin PR, O'Hara BR et al. (2013) Vegan: community ecology package. R package version 2.0-10.

Overpeck JT, Webb T III, Prentice IC (1985) Quantitative interpretation of fossil pollen spectra: dissimilarity coefficients and the method of modern analogs. Quat Res 23:87-108. https://doi.org/10.1016/ 0033-5894(85)90074-2

Paine RT, Tegner MJ, Johnson AE (1998) Compounded perturbations yield ecological surprises. Ecosystems 1:535-546. https://doi.org/ 10.1007/s100219900049

Pan Y, Birdey RA, Fang J, Houghton R, Kauppi PE et al (2011) A large and persistent carbon sink in the world's forests. Science 333:988993. https://doi.org/10.1126/science.1201609

Payne RJ, Egan J (2019) Using palaeoecological techniques to understand the impacts of past volcanic eruptions. Quat Int 499:278289. https://doi.org/10.1016/j.quaint.2017.12.019

R Development Core Team (2015) R: A language and environment for statistical computing ( $\mathrm{R}$ foundation for statistical computing, Vienna, 2015).

Reimer PJ, Bard E, Bayliss A, Beck JW, Blackwell PG et al (2013) IntCal13 and Marine13 radiocarbon age calibration curves 0-50,
000 years cal BP. Radiocarbon 55:1869-1887. https://doi.org/10. 2458/azu js_rc.55.16947

Rostain S, de Saulieu G, Lézy E (2014) El Alto Pastaza precolombino en Ecuador: del mito a la arqueología. In: Rostain S (ed) Amazonía: Memorias de las Conferencias Magistrales del $3^{\text {er }}$ encuentro Internacional de Arqueología Amazónica. Ekseption Publicidad, Ecuador, pp 159-186

Rull V (2006) A high mountain pollen-altitude calibration set for palaeoclimatic use in the tropical Andes. Holocene 16:105-117. https://doi.org/10.1191/0959683606hl909rp

Sakals ME, Innes JL, Wilford DJ, Sidle RC, Grant GE (2006) The role of forests in reducing hydrogeomorphic hazards. For Snow Landsc Res $80: 11-22$

Self AE, Klimaschewski A, Solovieva N, Jones VJ, Andrén E et al (2015) Holocene environmental changes inferred from a mountain lake in central Kamchatka. Glob Planet Chang 134:67-81. https://doi.org/ 10.1016/j.gloplacha.2015.06.012

Simpson GL (2007) Analogue methods in palaeoecology: using the analogue package. J Stat Softw 22(2). https://doi.org/10.18637/jss. v022.i02

Spracklen DV, Arnold SR, Taylor CM (2012) Observations of increased tropical rainfall preceded by air passage over forests. Nature 489: 282-285. https://doi.org/10.1038/nature11390

Swetnam TW, Allen CD, Betancourt JL (1999) Applied historical ecology: using the past to manage for the future. Ecol Appl 9:1189 1206. https://doi.org/10.1890/1051-0761(1999)009[1189: AHEUTP]2.0.CO;2

Publisher's note Springer Nature remains neutral with regard to jurisdictional claims in published maps and institutional affiliations. 